\title{
Application of Regression Models in Bird Population Data: An Example of Haçlı Lake
}

\section{Emrah ÇELIK ${ }^{1 *}$, Atilla DURMUŞ ${ }^{2}$}

\begin{abstract}
In this study, the effects of habitat, ordo, UTM frame, seasons and number of species on bird populations and distribution in Haçlı Lake were investigated. Bird population data were obtained using point counts and transect observation methods. Poisson regression is typically used in such data sets. The basic principle of Poisson regression assumes that the variance is equal to the mean. Failure to achieve this equality causes incorrect parameter estimates and standard errors. In practice, the variance is often higher than the mean (variance > mean). This is called over-dispersion, where the value of overdispersion is greater than 1.0. The population status of the data set used in the study was over-dispersed. Negative binomial regression is the most common method used to eliminate the over-dispersion effect. In this case, the preferred method is the negative binomial regression method. The over-dispersion value in the Poisson regression was considerably greater than 1.0 (54.937) while the over-dispersion value was very close to 1.0 (1.588) in the negative binomial regression. The results indicated that the use of negative binomial regression method is more appropriate. Therefore, parameter estimations were interpreted according to negative binomial regression method. Herein, climatic factors including temperature and humidity exhibited significant impacts on population density and number of species.
\end{abstract}

Keywords: Bird population, haçlı lake, negative binomial, over-dispersion, poisson regression

\footnotetext{
${ }^{1}$ Emrah ÇELİK (Orcid ID: 0000-0003-1274-4122), Igdir University, Vocational School of Technical Sciences, Department of Forestry-Hunting and Wildlife Program, Igdir, Turkey

${ }^{2}$ Atilla DURMUŞ (Orcid ID: 0000-0002-5116-9581), Van Yuzuncu Y1l University, Faculty of Science, Department of Biology, Zoology Major Science Branch, Van, Turkey

*Corresponding Author: Emrah ÇELIK, e-mail: celikemrah822@gmail.com
} 


\section{INTRODUCTION}

Every living species on earth has a particular environment and habitat (Adizel et al., 2010). Habitats are the main determinants of the distribution and abundance of organisms and form the fundamental of the conservation studies (O'Hara and Kotze, 2010; Boyce et al., 2016). The living organisms in the biosphere are in direct or indirect interaction with each other. Living organisms sharing the same food web and interacting with each other maintain their life span in equilibrium. Therefore, a living group in each step of the food chain possess great roles for the proper and sustainable ecosystem.

Birds, which are the biological indicators of the natural ecosystem, contribute to biodiversity with their habitat preferences and population densities (Kiziroğlu, 2008). Therefore, determining the species and population status of birds in an area is important to reveal the naturalness and ecological importance of the area. Searching for appropriate habitat and modelling the distribution of organisms are increasingly becoming important for ecology and conservation biology. Correlative species distribution models (SDM) assess the relationship between species distribution data and environmental factors, as well as determining habitat suitability for a focus species in a given area (Guisan and Zimmermann, 2000; Graham et al., 2004). Therefore, assessing the effects of these environmental factors on the distribution of living species is very important (Aksan et al., 2014).

Several ecological and environmental factors including vegetation structure (Clark and Shutler 1999; Milsom et al., 2000), human activities (Milsom et al., 2000; Yuan et al., 2014), temperature, precipitation, humidity (Girma et al., 2017), geographical structure (Li and Martin, 1991) and nutrient diversity (Beerens et al., 2011) affect the habitat preferences and geographical distribution of birds.

The most common technique used to determine the bird populations is the counting method (Bibby and Burgess, 2000). Counting studies are typically used to identify changes occurred in the number of organisms in wildlife (Knape et al., 2018). Numerous statistical methods are used in the analysis of the data obtained by counting. Independent data obtained by counting can show Poisson distribution (PD) and are analyzed by Poisson regression (PR) (Ridout, 1998).

The basic principle of Poisson distribution is that the mean and variance are equal (Yeşilova and Denizhan, 2016). However, the counting data, in actual applications, does not always support Poission distribution (Muthen and Muthen, 2006). Over-dispersion is often encountered where the variance is greater than mean (Ver Hoef and Boveng, 2007). In order to eliminate the over-dispersion, negative binomial regression binomial is of the used regression tools (Agresti, 1997; Hilbe, 2007). There are examples of negative binomial regression in many different studies. The negative binomial regression model have been used in many studies including the determination of species richness (O'Hara, 2005), parasite determination in birds (Rekasi et al., 1997), bird population densities (Durmuş et al,, 2018; Çelik and Durmuş, 2020), identifying the environmental variables affecting bird migration (Lindén and Mantyniemi, 2011) and estimating the direction and abundance parameters of water seal (Small et al., 2003; Kery et al., 2005).

In this study, Poisson regression and negative binomial regression were used in order to determine the effects of habitat, ordo, UTM frame, seasons and number of species on bird populations and distribution in Haçlı Lake (Muş, Turkey).

\section{MATERIALS AND METHODS}

The materials of this study are the Haçlı Lake located in Euphrates-Tigris River Basin of Turkey (38 S $265952 \mathrm{~N} 4322968 \mathrm{E}$ ) and the birds that use the delta for living purpose. The observations on population density were conducted by 15 day-period in each month, covering 4 seasons between April 2016 - September 2017 and the numerical data obtained were obtained by 18 months of field studies. 
Observations depending on seasonal conditions started with sunrise and ended with sunset. The study area has been divided into 54 UTM squares of $1 \times 1 \mathrm{~km}^{2}$ (Figure 1). Three observation points were used, at least $300 \mathrm{~m}$ far from each other and representing the habitats in each UTM square.

Observation along a Line (line transect) and Point Observation Method (point counts) were used in observations to determine population density and number of individuals (Bibby and Burgess, 2000). Bird species and population numbers identified in the point and surrounding area and UTM coordinates were recorded on field observation cards. The point records obtained in the study were then assigned to UTM squares and subsequently used. This process has enabled the possibility of analysis on a grid basis in addition to the point scale (Onmuş, 2008)

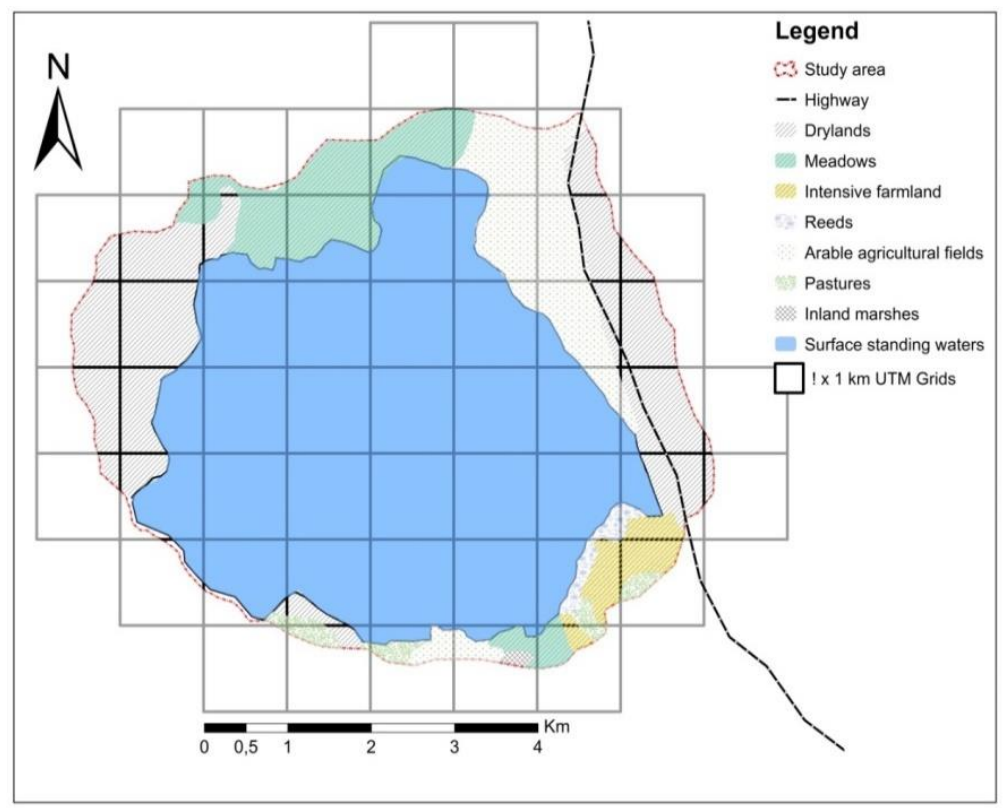

Figure 1. Location of the study area, $1 \times 1 \mathrm{~km}$ UTM squares, and the major habitats

\section{Statistical Analysis}

Poisson regression: Poisson regression analysis is of the used statistical methods in assumption of dependent variable that is observed event number $\left(y_{i}\right)$ and exhibits a Poisson distribution. Poisson mean logarithm $(\mu)$ is deemed to be a linear function of the independent variables (Equation 1) (Yeşilova et al., 2016). Herewith the Poisson regression analysis, maximum likelihood estimation (ML) method is used for parameter estimation. Likelihood function for nonlinear Poisson regression model can be written as follow;

$$
\ln L=\sum_{i=1}^{n}\left[-\lambda_{i}+y_{i} x_{i}^{\prime} \beta-\ln y_{i} !\right]=\sum_{i=1}^{n}\left[-e^{\mathbf{x}_{i}^{\prime} \beta}+y_{i} x_{i}^{\prime} \beta-\ln y_{i} !\right] \text { (Equation 1) }
$$

Negative binomial regression: Negative binomial regression model is represented as follows (Hilbe, 2007). For the equation, the auxiliary parameter indicates over-dispersion degree and $\mathrm{k}$ is considered as a positive value (Equation 2).

$$
P\left(Y=y \mid X_{1}, X_{2}, X_{3}, k\right)=\frac{\Gamma(y+k)}{\Gamma(k) \Gamma(y+1)}\left(\frac{k}{k+\mu}\right)^{k}\left(\frac{\mu}{k+\mu}\right)^{y} \quad y=0,1,2, \ldots \quad \text { (Equation 2) }
$$

Bird population data in Haçlı Lake were used as a model dependent variable. In addition, seasons, ordo and frames were modelled as independent variables and Poisson and negative binomial regressions 
were applied respectively. Necessary statistical analyses were performed using SAS 9.1.1.4 statistical software program.

\section{RESULTS AND DISCUSSION}

The results of study carried out for approximately two years indicated the existence of 117 species and 1 subspecies belonging to 14 ordo and 34 families in Haçlı Lake. Of these species, 35.6\% (n: 42) were native, $52.5 \%$ (n: 62) were migrants, $10.2 \%$ (n: 12) were winter visitors and $1.7 \%$ (n: 2) were transit migrants. The observations conducted during the reproduction period indicated that 13 species certainly breeding, 12 species probably breeding based on the observations such as courtship behaviour and existence of male and female individuals and 93 species do not produce in the study area. Seven habitat types based on geographical, topographic and floristic characteristics were identified within the boundaries of the study area. The habitats and population status of the ordo groups present in the area were determined by periodical observations during the four seasons (Table 1).

Table 1. Population densities, number of UTM square used and seasonal habitat distributions of ordos defined in Haçlı Lake

\begin{tabular}{|c|c|c|c|c|c|}
\hline Ordo & Number of species & Population density & Season & Habitat type & Square \\
\hline 201 & 2 & 106 & 11 & 2 & 8 \\
\hline 201 & 7 & 128 & 11 & 4 & 5 \\
\hline 201 & 1 & 20 & 11 & 7 & 2 \\
\hline 201 & 5 & 98 & 22 & 4 & 3 \\
\hline 201 & 1 & 7 & 22 & 7 & 2 \\
\hline 201 & 3 & 141 & 22 & 8 & 4 \\
\hline 201 & 2 & 11 & 33 & 3 & 2 \\
\hline 201 & 5 & 84 & 33 & 8 & 3 \\
\hline 201 & 2 & 126 & 44 & 7 & 1 \\
\hline 202 & 1 & 8 & 22 & 3 & 1 \\
\hline 203 & 1 & 1 & 11 & 1 & 1 \\
\hline 203 & 1 & 45 & 22 & 2 & 1 \\
\hline 204 & 3 & 298 & 11 & 2 & 6 \\
\hline 204 & 4 & 108 & 11 & 4 & 3 \\
\hline 204 & 5 & 264 & 11 & 7 & 4 \\
\hline 204 & 1 & 770 & 11 & 8 & 3 \\
\hline 204 & 2 & 24 & 22 & 2 & 1 \\
\hline 204 & 3 & 43 & 22 & 4 & 2 \\
\hline 204 & 2 & 963 & 22 & 5 & 3 \\
\hline 204 & 8 & 1609 & 22 & 7 & 3 \\
\hline 204 & 1 & 184 & 22 & 8 & 1 \\
\hline 204 & 1 & 13 & 33 & 2 & 2 \\
\hline 204 & 1 & 5 & 33 & 4 & 1 \\
\hline 204 & 2 & 201 & 33 & 5 & 6 \\
\hline 204 & 6 & 337 & 33 & 7 & 5 \\
\hline 204 & 1 & 32 & 44 & 4 & 1 \\
\hline 205 & 2 & 70 & 11 & 2 & 1 \\
\hline 205 & 1 & 19 & 22 & 2 & 1 \\
\hline 205 & 1 & 43 & 22 & 5 & 1 \\
\hline 205 & 1 & 18 & 33 & 5 & 1 \\
\hline 206 & 2 & 91 & 22 & 3 & 3 \\
\hline 206 & 4 & 124 & 33 & 3 & 3 \\
\hline 206 & 1 & 164 & 44 & 7 & 2 \\
\hline 207 & 1 & 27 & 11 & 1 & 1 \\
\hline 207 & 1 & 5 & 11 & 2 & 1 \\
\hline 207 & 2 & 226 & 22 & 1 & 2 \\
\hline 207 & 1 & 4 & 22 & 2 & 1 \\
\hline 207 & 2 & 54 & 33 & 1 & 2 \\
\hline 207 & 1 & 1 & 33 & 2 & 1 \\
\hline
\end{tabular}


Table 1. (cont.)

\begin{tabular}{|c|c|c|c|c|c|}
\hline Ordo & Number of species & Population density & Season & Habitat type & Square \\
\hline 208 & 1 & 3 & 11 & 2 & 1 \\
\hline 208 & 2 & 3 & 11 & 7 & 2 \\
\hline 208 & 6 & 29 & 22 & 2 & 1 \\
\hline 208 & 2 & 3 & 22 & 4 & 1 \\
\hline 208 & 1 & 4 & 22 & 7 & 1 \\
\hline 208 & 4 & 19 & 33 & 2 & 1 \\
\hline 208 & 1 & 4 & 33 & 4 & 1 \\
\hline 208 & 1 & 4 & 33 & 8 & 1 \\
\hline 208 & 2 & 5 & 44 & 7 & 2 \\
\hline 209 & 1 & 60 & 11 & 4 & 2 \\
\hline 209 & 1 & 320 & 11 & 7 & 4 \\
\hline 209 & 1 & 1352 & 22 & 8 & 2 \\
\hline 209 & 1 & 480 & 33 & 8 & 6 \\
\hline 210 & 3 & 166 & 11 & 1 & 2 \\
\hline 210 & 2 & 3 & 11 & 2 & 1 \\
\hline 210 & 10 & 132 & 11 & 3 & 1 \\
\hline 210 & 7 & 66 & 11 & 4 & 1 \\
\hline 210 & 11 & 451 & 22 & 1 & 3 \\
\hline 210 & 8 & 484 & 22 & 2 & 3 \\
\hline 210 & 17 & 709 & 22 & 3 & 3 \\
\hline 210 & 13 & 63 & 22 & 4 & 1 \\
\hline 210 & 3 & 406 & 22 & 5 & 2 \\
\hline 210 & 4 & 82 & 22 & 7 & 1 \\
\hline 210 & 4 & 74 & 33 & 1 & 1 \\
\hline 210 & 14 & 103 & 33 & 2 & 2 \\
\hline 210 & 16 & 350 & 33 & 3 & 6 \\
\hline 210 & 5 & 23 & 33 & 4 & 1 \\
\hline 210 & 2 & 6 & 33 & 7 & 1 \\
\hline 210 & 14 & 523 & 44 & 7 & 6 \\
\hline 211 & 5 & 95 & 11 & 2 & 1 \\
\hline 211 & 1 & 20 & 11 & 4 & 1 \\
\hline 211 & 3 & 27 & 22 & 2 & 1 \\
\hline 211 & 4 & 135 & 22 & 7 & 1 \\
\hline 211 & 2 & 4 & 33 & 6 & 1 \\
\hline 211 & 2 & 50 & 33 & 7 & 2 \\
\hline 211 & 1 & 2 & 33 & 8 & 1 \\
\hline 211 & 1 & 4 & 44 & 7 & 1 \\
\hline 212 & 1 & 35 & 11 & 4 & 1 \\
\hline 212 & 3 & 915 & 22 & 8 & 2 \\
\hline 212 & 3 & 303 & 33 & 8 & 4 \\
\hline 213 & 1 & 2 & 22 & 1 & 1 \\
\hline 214 & 1 & 7 & 11 & 8 & 2 \\
\hline 214 & 1 & 18 & 22 & 4 & 1 \\
\hline
\end{tabular}

Numerical data obtained from habitat based observations were arranged for statistical analysis. The population density of the birds in the ordo the number of UTM squares used, as well as the population densities varying depending on the seasons and habitat structures were determined.

\section{Statistical Model}

Bird population data obtained by counting in the study area were used as dependent variable of the model. Seasons, ordo, habitat and squares were modelled as independent variables and Poisson and negative binomial regressions were applied respectively. The bird counts used as dependent variable of the model was represented in Figure 2. As seen from Figure 2, the distribution regarding the data of the present study is skewed right. The extreme skewness to the right in such data does not change much despite the transformations (Agresti, 1997; Cameron et al., 1998). 


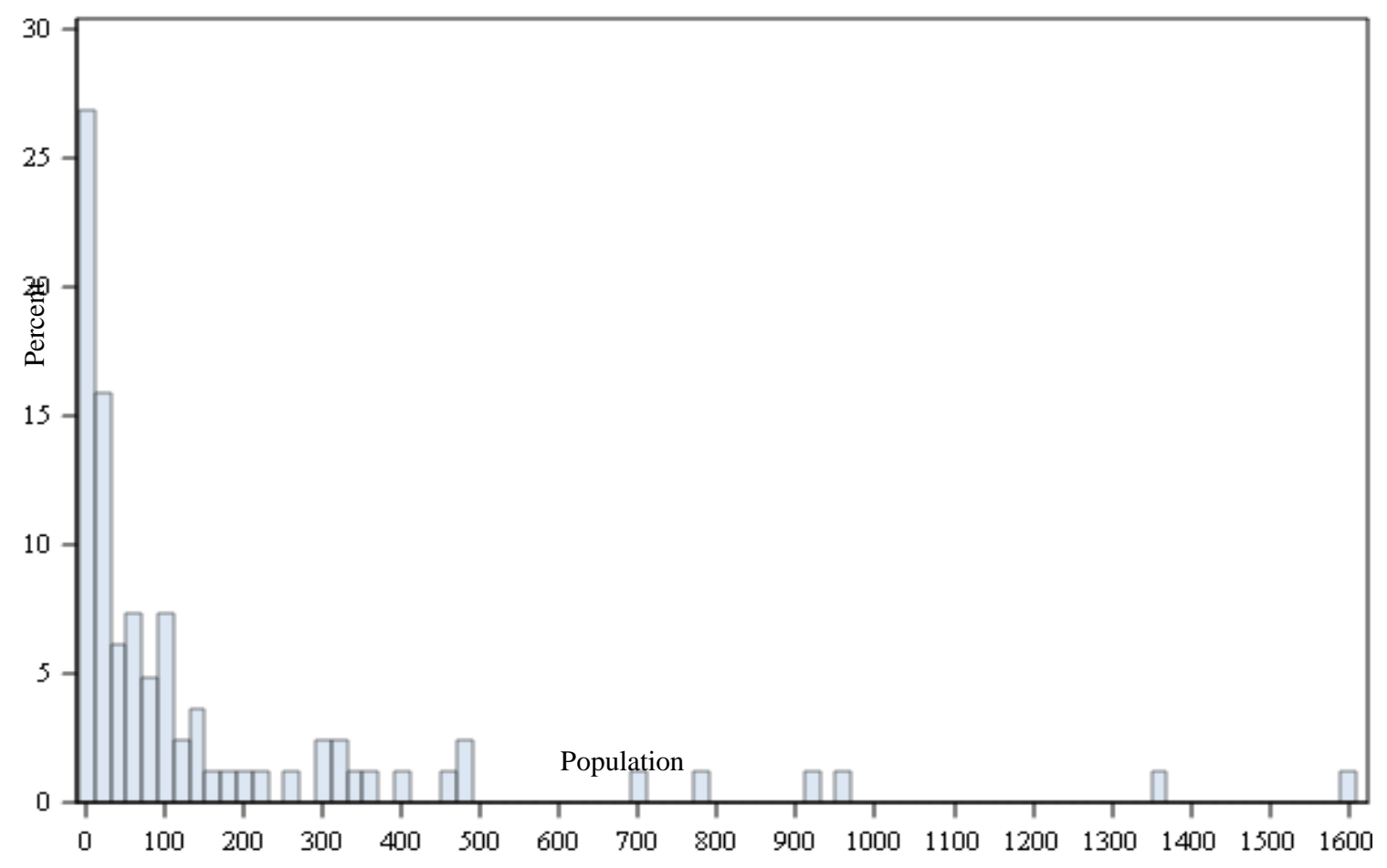

Figure 2. Bird population density graph of Haçlı Lake

Compliance criteria for Poisson and negative binomial regression were given in Table 2. The overdispersion value was obtained through division of deviance statistics using their degrees of freedom. The over-dispersion value in Poisson regression was considerably greater than 1.0 (54.937) while overdispersion value in negative binomial regression was very close to 1.0 (1.588). According to deviance criterion, dependent variable exhibited a large over-dispersion. Thus, negative binomial regression was used. Parameter estimation values and standard errors of Poisson and negative binomial regressions were given in Table 3-4. The effect of the over-dispersion values was reflected in both regression methods. Estimates obtained for independent variables were quite different for Poisson regression and negative binomial regression, indicating the effects of over-dispersion on parameter estimations.

Table 2. Compliance criteria for Poisson and negative binomial regression models

\begin{tabular}{lccc}
\hline Models & Df & Devians statistics $^{*}$ & Over-dispersion*** $^{*}$ \\
\hline Poisson regression & 56 & 3076.4920 & 54.937 \\
Negative binomial regression & 56 & 88.9479 & 1.588 \\
\hline
\end{tabular}

${ }^{*} \mathrm{Df}=$ degree of freedom, ${ }^{* *}$ Devians statistics $/ \mathrm{Sd}$

The variation in the populations of Bucerotiformes and Caprimulgiformes ordo groups, according to the reference parameter of the Anseriformes ordo, were not statistically significant. However, the increase and decrease in the populations of Ciconiiformes $(p<0.05)$, Falconiformes, Strigiformes, Suliformes, Charadriiformes, Coraciiformes, Columbiformes, Gruiformes, Passeriformes Pelecaniformes and Podicipediformes ordo groups were statistically significant $(p<0.01)$ (Table 3$)$. The population changes in spring, summer and autumn seasons, according to winter reference parameter, were statistically significant $(p<0.01)$. The population changes in arid land, meadow, cultivated field, irrigated field, swamp and open water surface habitats, according to the reed area reference parameter, were statistically significant $(p<0.01)$, whereas the difference in the pasture habitat was not significant. 
The increase in the number of species caused a 1.224-fold increase in population density and a one-unit increase in the number of UTM squares used by the species caused a 1.212-fold increase in population density and the increases were statistically significant $(p<0.01)$ (Table 3 ).

Negative binomial regression results showed that population changes in 7 ordo groups were not significant according to the Anseriformes ordo reference parameter. However, the population decreases and increases in Charadriiformes, Columbiformes and Podicipediformes ordo groups $(p<0.05)$ and Falconiformes, Strigiformes and Gruiformes ordo groups $(p<0.01)$ were statistically significant (Table $4)$. The population changes in the spring and autumn seasons were not statistically significant $(p>0.05)$ according to the winter parameter, whereas summer population changes were significant. The population variations in arid area, irrigated field and open water surface were significant $(p<0.01)$ according to reed area the reference parameter. Population changes in meadows and marshes were found to be statistically significant $(p<0.05)$, however, population changes in cultivated farmland and pasture areas were not significant The increase in the number of species and one unit increase in the number of UTM squares caused a significant increase in population density.

The over-dispersion value of the dependent variable was quite high (Table 3-4) and subsequently caused different parameter estimation values and standard errors in both regression models. The interpretation of parameter estimates for both regression models exhibits differences from that of linear regression. The Poisson regression and the negative binomial regression models should be linearized using the log link function to estimate how much each individual variable has effect on the dependent variable.

In regression models based on generalized linear models such as Poisson and Negative binomial, one level of each independent variable is typically used as reference category (Luo and Qu 2015; Yeşilova et al., 2016). Therefore, Anseriformes for ordo, winter for seasons, reeds for habitats, number of species and UTM square numbers were considered as reference levels.

The inflence of independent variables on bird populations were analysed and the results were given in Table 3 and Table 4. However, independent variables, ordo (team) (Anseriformes, Bucerotiformes, Caprimulgiformes, Charadriiformes, Ciconiiformes, Coraciiformes, Cuculiformes, Falconiformes, Gruiformes, Passeriformes, Pelecaniformes, Podicipediformes, Strigiformes, Suliformes), the number of species, the number of UTM used, seasons (summer, autumn and winter) and habitats (open water surface, swamps, reeds, arid lands, irrigated lands, cultivated lands, pastures and meadows) have different levels. Therefore, each independent variable level should be tested independently to assess the importance of individual effect on bird populations.

Since negative binomial regression was the best regression model according to the compliance criterion, only the results of binomial regression were interpreted (Table 4). Accordingly, it was found that population decreases and increases were statistically significant in Charadriiformes, Columbiformes and Podicipediformes ordo groups ( $p<0.05$ ), Falconiformes, Strigiformes and Gruiformes ordo groups $(p<0.01)$. One unit increase in the number of species and UTM square led to the population increase by $1.215(p<0.01)$ and $1.056(p<0.05)$ times, respectively. Population changes between seasons and habitats were statistically significant.

The population in the summer season significantly $(p<0.01)$ increased compared to the reference parameter of winter while the population increase and decrease in spring and autumn were not significant. The population changes only in cultivated lands and pasture areas, according to the habitat reference parameter were not significant. 
Table 3. Poisson regression model parameter estimation values and standard error obtained for Haçli Lake (sd. error)

\begin{tabular}{|c|c|c|c|c|c|c|c|c|}
\hline \multirow{2}{*}{$\frac{\text { Parameters }}{\text { Intercept }}$} & \multirow{2}{*}{$\frac{\text { Df }}{1}$} & \multirow{2}{*}{$\begin{array}{c}\text { Estimate } \\
0.1372\end{array}$} & \multirow{2}{*}{$\frac{\text { Standard error }}{0.1114}$} & \multicolumn{2}{|c|}{$\begin{array}{c}\text { \%95 Wald confidence } \\
\text { interval }\end{array}$} & \multirow{2}{*}{$\begin{array}{c}\text { Wald Khi-square } \\
\text { value }\end{array}$} & \multirow{2}{*}{$\frac{\text { p-value }}{0.2182}$} & \multirow{2}{*}{$\frac{\text { Exp. }}{1.147}$} \\
\hline & & & & -0.0811 & 0.3555 & & & \\
\hline Bucerotiformes & 1 & -0.6196 & 0.3647 & -1.3343 & 0.0952 & 2.89 & 0.0893 & 0.538 \\
\hline Caprimulgiformes & 1 & -0.1780 & 0.1617 & -0.4949 & 0.1390 & 1.21 & 0.2710 & 0.836 \\
\hline Charadriiformes & 1 & 1.4737 & 0.0462 & 1.3832 & 1.5642 & 1019.55 & $0.0001 * *$ & 4.365 \\
\hline Ciconiiformes & 1 & -0.2142 & 0.1021 & -0.4143 & -0.0141 & 4.40 & $0.0359 *$ & 0.807 \\
\hline Columbiformes & 1 & 1.7610 & 0.1016 & 1.5619 & 1.9601 & 300.47 & $0.0001 * *$ & 5.818 \\
\hline Coraciiformes & 1 & 0.7283 & 0.0873 & 0.5571 & 0.8994 & 69.56 & $0.0001 * *$ & 2.071 \\
\hline Falconiformes & 1 & -1.1951 & 0.1287 & -1.4474 & -0.9428 & 86.22 & $0.0001 * *$ & 0.302 \\
\hline Gruiformes & 1 & 2.1545 & 0.0465 & 2.0634 & 2.2456 & 2150.54 & $0.0001 * *$ & 8.623 \\
\hline Passeriformes & 1 & 0.4004 & 0.0652 & 0.2726 & 0.5282 & 37.69 & $0.0001 * *$ & 1.492 \\
\hline Pelecaniformes & 1 & 0.4179 & 0.0786 & 0.2638 & 0.5720 & 28.25 & $0.0001 * *$ & 1.518 \\
\hline Podicipediformes & 1 & 1.5518 & 0.0517 & 1.4505 & 1.6531 & 901.21 & $0.0001 * *$ & 4.719 \\
\hline Strigiformes & 1 & -2.9976 & 0.7112 & -4.3915 & -1.6037 & 17.77 & $0.0001 * *$ & 0.049 \\
\hline Suliformes & 1 & -1.3981 & 0.2060 & -1.8019 & -0.9943 & 46.06 & $0.0001 * *$ & 0.247 \\
\hline Number of species & 1 & 0.2024 & 0.0056 & 0.1914 & 0.2134 & 1305.16 & $0.0001 * *$ & 1.224 \\
\hline Spring & 1 & 1.5288 & 0.0750 & 1.3817 & 1.6758 & 415.32 & $0.0001 * *$ & 4.612 \\
\hline Summer & 1 & 1.8864 & 0.0708 & 1.7476 & 2.0252 & 709.34 & $0.0001 * *$ & 6.595 \\
\hline Autumn & 1 & 0.4110 & 0.0670 & 0.2796 & 0.5424 & 37.60 & $0.0001 * *$ & 1.508 \\
\hline Dry lands & 1 & 1.2725 & 0.0601 & 1.1548 & 1.3902 & 448.89 & $0.0001 * *$ & 3.569 \\
\hline Meadows & 1 & 0.8751 & 0.0521 & 0.7730 & 0.9772 & 282.29 & $0.0001 * *$ & 2.399 \\
\hline Intensive farmland & 1 & 0.2807 & 0.0648 & 0.1537 & 0.4077 & 18.78 & $0.0001 * *$ & 1.324 \\
\hline Arable agricultural fields & 1 & 2.2872 & 0.0617 & 2.1663 & 2.4081 & 1375.29 & $0.0001 * *$ & 9.847 \\
\hline Pastures & 1 & -0.1769 & 0.5053 & -1.1674 & 0.8135 & 0.12 & 0.7263 & 0.837 \\
\hline Inland marshes & 1 & 1.3669 & 0.0458 & 1.2772 & 1.4567 & 890.98 & $0.0001 * *$ & 3.923 \\
\hline Surface standing waters & 1 & 2.2464 & 0.0508 & 2.1467 & 2.3460 & 1953.32 & $0.0001 * *$ & 9.453 \\
\hline UTM & 1 & 0.1923 & 0.0099 & 0.1729 & 0.2118 & 373.91 & $0.0001 * *$ & 1.212 \\
\hline
\end{tabular}

$\mathrm{Df}=$ Degrees of freedom $* \mathrm{p}<0.05, * * \mathrm{p}<0.01$

Table 4. Negative binomial regression model parameter estimation values and standard error obtained for Haçlı Lake (sd. error)

\begin{tabular}{|c|c|c|c|c|c|c|c|c|}
\hline Parameters & Df & Estimate & $\begin{array}{l}\text { Standard } \\
\text { error }\end{array}$ & $\% 95$ Wald & dence interval & $\begin{array}{c}\text { Wald Khi-square } \\
\text { value }\end{array}$ & p-value & Exp. \\
\hline Intercept & 1 & 1.4190 & 0.4849 & 0.4686 & 2.3694 & 8.56 & 0.0034 & 4.132 \\
\hline Bucerotiformes & 1 & -1.1081 & 1.0007 & -3.0695 & 0.8533 & 1.23 & 0.2682 & 0.330 \\
\hline Caprimulgiformes & 1 & -0.5850 & 0.6976 & -1.9523 & 0.7823 & 0.70 & 0.4017 & 0.110 \\
\hline Charadriiformes & 1 & 0.8891 & 0.3648 & 0.1741 & 1.6040 & 5.94 & $0.0148 *$ & 2.432 \\
\hline Ciconiiformes & 1 & -0.2123 & 0.5728 & -1.3350 & 0.9105 & 0.14 & 0.7110 & 0.808 \\
\hline Columbiformes & 1 & 1.1797 & 0.5980 & 0.0076 & 2.3518 & 3.89 & $0.0485 *$ & 3.253 \\
\hline Coraciiformes & 1 & -0.9688 & 0.5865 & -2.1183 & 0.1808 & 2.73 & 0.0986 & 0.379 \\
\hline Falconiformes & 1 & -1.4593 & 0.4608 & -2.3624 & -0.5562 & 10.03 & $0.0015 * *$ & 0.232 \\
\hline Gruiformes & 1 & 1.8858 & 0.4980 & 0.9097 & 2.8619 & 14.34 & $0.0002 * *$ & 6.591 \\
\hline Passeriformes & 1 & -0.3444 & 0.4440 & -1.2146 & 0.5257 & 0.60 & 0.4379 & 0.708 \\
\hline Pelecaniformes & 1 & -0.0062 & 0.4629 & -0.9136 & 0.9011 & 0.00 & 0.9893 & 0.993 \\
\hline Podicipediformes & 1 & 1.2663 & 0.5544 & 0.1796 & 2.3530 & 5.22 & $0.0224 *$ & 3.547 \\
\hline Strigiformes & 1 & -4.4282 & 1.1786 & -6.7383 & -2.1181 & 14.12 & $0.0002 * *$ & 0.011 \\
\hline Suliformes & 1 & -0.7869 & 0.6762 & -2.1121 & 0.5384 & 1.35 & 0.2445 & 0.455 \\
\hline Number of species & 1 & 0.2352 & 0.0487 & 0.1397 & 0.3306 & 23.33 & $0.0001 * *$ & 1.265 \\
\hline Spring & 1 & 0.7717 & 0.4828 & -0.1745 & 1.7179 & 2.56 & 0.1099 & 2.163 \\
\hline Summer & 1 & 1.1831 & 0.4432 & 0.3145 & 2.0518 & 7.13 & $0.0076 * *$ & 3.264 \\
\hline Autumn & 1 & 0.0459 & 0.4619 & -0.8594 & 0.9512 & 0.01 & 0.9209 & 1.046 \\
\hline Dry lands & 1 & 2.0966 & 0.5029 & 1.1110 & 3.0822 & 17.38 & $0.0001 * *$ & 8.138 \\
\hline Meadows & 1 & 0.6568 & 0.3284 & 0.0130 & 1.3005 & 4.00 & $0.0455^{*}$ & 1.928 \\
\hline Intensive farmland & 1 & 0.1628 & 0.4940 & -0.8054 & 1.1310 & 0.11 & 0.7417 & 1.176 \\
\hline Arable agricultural fields & 1 & 1.9419 & 0.4893 & 0.9829 & 2.9010 & 15.75 & $0.0001 * *$ & 6.971 \\
\hline Pastures & 1 & -0.7302 & 0.9806 & -2.6522 & 1.1918 & 0.55 & 0.4565 & 0.481 \\
\hline Inland marshes & 1 & 0.8473 & 0.3306 & 0.1994 & 1.4953 & 6.57 & $0.0104 *$ & 2.333 \\
\hline Surface standing waters & 1 & 1.5878 & 0.3588 & 0.8847 & 2.2910 & 19.59 & $0.0001 * *$ & 4.892 \\
\hline UTM & 1 & 0.1874 & 0.0839 & 0.0230 & 0.3518 & 4.99 & $0.0254 *$ & 1.206 \\
\hline
\end{tabular}

$\mathrm{Df}=$ Degrees of freedom $* \mathrm{p}<0.05, * * \mathrm{p}<0.01$ 


\section{CONCLUSION}

The result of deviance statistics revealed a significant over-dispersion of the dependent variable. Therefore, the use of negative binomial regression was considered more appropriate to evaluate the parameters. Parameter estimates were quite different in both Poisson and negative binomial regressions.

The categorical independent variables of Haçlı Lake model are Anseriformes ordo, reeds and winter season which were considered as references. The significance levels of these independent variables on population density were given as follows. Comparision of Anseriformes ordo with the other ordos revealed that the populations of 9 ordos decreased, however the decrease in population was only statistically significant $(p<0.01)$ for the Falconiformes ordo. However, the population densities of the 4 ordo increased compared to the reference. The population was increased in Charadriiformes $(p<0.05)$, Columbiformes $(p<0.05)$, Podicipediformes $(p<0.05)$ and Gruiformes $(p<0.01)$ ordos.

Population differences between ordos were attributed to the contribution of Armenian gull (Larus armenicus), Rock pigeon (Columba livia), Common coot (Fulica atra) and Little Grebe (Tachybaptus ruficollis) which are seen in all seasons in the area. The intense presence of species such as Redshank (Tringa totanus), Common tern (Sterna hirundo), Ruddy shelduck (Tadorna ferruginea) and Lapwing (Vanellus vanellus) in the study area during the reproduction period cause the differences between populations. The differences in feeding area of species are another reason for the increase and decrease in population density. The wetlands around the lake are suitable feeding areas for the shore birds, while the coastal reeds and the lake mirror are suitable feeding areas for diving or surface feeding birds. However, in some cases, different species have been observed feeding in the same feeding areas. Therefore, similarities and differences in feeding areas either facilitated for some species to find food or made it difficult for others and caused them to leave. This resulted in an increase in population densities of some ordos and a decrease in others. Guisan et al. (2007) stated that the population status of birds differs from species to species, and population trends may change by vital activities and habitat preferences. Beerens et al. (2011) reported that seasonal and annual nutritional diversity in the reproduction period plays an active role in the population mobility of many bird species. They also stated that the bird species in extremely lively ecosystems such as wetlands have different population densities and habitat preferences, which vary according to vital activities such as finding and using food resources.

Comparison of reeds considered the reference habitat, with other habitat types, indicated that population increases in arid lands, irrigated lands and on open water surface were statistically significant at $p<0.01$ level while the population increase at meadows and swamp areas were statistically significant at $p<0.05$ level. Human activities around the lake are the main causes of the differences in bird populations among habitats. Reed cutting is intensively performed around the lake in spring-summer (after reproduction period) seasons. Reed cutting during the reproduction period has a negative effect on the birds living in this habitat. Reed cutting has endangered the vital activities of birds such as hiding and shelter. In this case, the birds scattered to different habitats to continue their activities such as feeding and hiding. Consequently, population density in the reeds area decreased compared to the other habitats. Similarly, Milsom et al. (2000) and Yuan et al. (2014) emphasized that human activities have negative impacts on the distribution, density and reproductive success of birds.

Comparing winter that is the reference season with other seasons, the population increase in spring and autumn seasons was not significant, however, the population increase in summer was statistically significant $(p<0.01)$. The population increase in the summer compared to the winter season is related to the contribution of the hatching individuals with the arrival of migratory species to the number of populations. The hatching individuals of Ruddy shelduck (Tadorna ferruginea), Lapwing (Vanellus 
vanellus), Common tern (Sterna hirundo) and Redshank (Tringa totanus) species which nest in colonies in the area during spring season significantly increase the population density in the summer season. These species are migratory and leaving the area before the winter season, which explains the population differences between the seasons. Johnston et al. (2015) also showed that the distribution and density of birds vary depending on species and seasons.

The temperature rise during the summer season increased the living activity in the area, which had a positive effect on the population density and caused to the difference in population density between summer and winter seasons. The effect of temperature variable on population density and number of species was demonstrated by Gonçalves et al. (2017) who emphasized that climatic factors such as temperature and humidity have a significant effect on the number of species and population density.

\section{ACKNOWLEDGEMENT}

This study is a part of the $\mathrm{PhD}$ thesis project "FDK-2016-5176" funded by Directorate of Scientific Research Projects of Yuzuncu Y1l University.

\section{REFERENCES}

Adızel Ö, Özdemir K, Durmuş A, Akın G, 2010. Genetiği Değiştirilmiş Organizmaların (GDO) Doğa ve İnsana Etkileri. Yüzüncü Y1l Üniversitesi, Fen Bilimleri Enstitüsü Dergisi, 15 (2): 148-153.

Agresti A, 1997. Categorical Data Analysis. John and Wiley \& Sons, Incorporation, New Jersey, Canada

Aksan Ş, Özdemir İ, Oğurlu İ, 2014. Modeling the distributions of some wild mammalian species in Gölcük Natural Park/Turkey. Biological Diversity and Conservation, 7 (1): 1-15.

Beerens JM, Gawlik DE, Herring G, Cook MI, 2011. Dynamic habitat selection by two wading bird species with divergent foraging strategies in a seasonally fluctuating wetland. The Auk, 128 (4): 651-662.

Bibby CJ, Burgess DN, Hill AD, Mustoe S, 2000. Bird Census Techniques, Second Edition, Academic Press, ISBN 012-095831-7, London, United Kingdom, 86.

Boyce MS, Johnson CJ, Merrill EH, Nielsen SE, Solberg EJ, Van Moorter B, 2016. Can habitat selection predict abundance? Journal of Animal Ecology, 85 (1): 11-20.

Cameron AC, Trivedi PK, 2013. Regression analysis of count data (Vol. 53). Cambridge University press.

Clark RG, Shutler D, 1999. Avian habitat selection: pattern from process in nest-site use by ducks? Ecology, 80 (1): 272-287.

Çelik E, Durmuş A, 2020. Nonlinear Regression Applications in Modeling Over-dispersion of Bird Populations. The Journal of Animal \& Plant Sciences, 30(2): 345-354.

Dalrymple ML, Hudson IL, Ford RPK, 2003. Finite mixture, zero-inflated poisson and hurdle models with application to SIDS. Computational Statistics and Data Analysis, 41: 491-504

Durmuş A, Yeşilova A, Çelik E, Kara R, 2018. Using Poisson and Negative Binomial Regression Models on Birds Population in Dönemeç Delta. Yuzuncu Y1l Unıversity Journal of Agricultural Sciences, 28 (1): 78-85.

Famoye F, Karan PS, 2006. Zero- inflated generalized poisson regression model with an application to domestic violence data. Journal of Data Science, 5: 117-130.

Girma Z, Mamo Y, Mengesha G, Verma A, Asfaw T, 2017. Seasonal abundance and habitat use of bird species in and around Wondo Genet Forest, south-central Ethiopia. Ecology and Evolution, 7 (10): 3397-3405.

Gonçalves GR, Santos MPD, Cerqueira PV, Juen L, Bispo AÂ, 2017. The relationship between bird distribution patterns and environmental factors in an ecotone area of northeast Brazil. Journal of Arid Environments, 140: 613

Graham CH, Ferrier S, Huettman F, Morit C, Peterson AT, 2004. New developments in museum-based informatics and applications in biodiversity analysis. Trends in Ecology and Evolution, 19: 497-503.

Guisan A, Graham CH, Elith J, Huettmann F, NCEAS. Species Distribution Modelling Group, 2007. Sensitivity of predictive species distribution models to change in grain size. Diversity and Distributions, 13 (3): 332-340.

Guisan A, Zimmermann NE, 2000. Predictive Habitat Distribution Models İn Ecology. Ecological Modelling, 135: 147-186. 
Hilbe JM, 2007. Negative Binomial Regression. Cambridge, U.K.

Johnston A, Fink D, Reynolds MD, Hochachka WM, Sullivan BL, Bruns NE, Kelling S, 2015. Abundance models improve spatial and temporal prioritization of conservation resources. Ecological Applications, 25 (7): 17491756.

Kéry M, Royle JA, Schmid H, 2005. Modeling avian abundance from replicated counts using binomial mixture models. Ecological applications, 15 (4): 1450-1461.

Kiziroğlu İ, 2008. Türkiye Kuşları. Tür Listesi ve Türkiye Kuşları Kırmızı Listesi. Hacettepe Üniversitesi, Çevre Eğitimi, Kuş Araştırmaları ve Halkalama Merkezi, Ankara. 86.

Knape J, Arlt D, Barraquand F, Berg Å, Chevalier M, Pärt T, Żmihorski M, 2018. Sensitivity of binomial N-mixture models to overdispersion: The importance of assessing model fit. Methods in Ecology and Evolution, 9 (10): 2102-2114.

Li P, Martin TE, 1991. Nest-Site Selection and Nesting Success of Cavity Nesting Birds in High Elevation Forest Drainages. Auk, 108: 405-418.

Lindén A, Mäntyniemi S, 2011. Using the negative binomial distribution to model overdispersion in ecological count data. Ecology, 92 (7): 1414-1421.

Luo J, Qu Y, 2015. Estimation of group means when adjusting for covariates in generalized linear models. Pharm Stat., 14 (1): 56-62.

Mathews EA, Pendleton GW, 2006. Declines in harbor seal (Phoca vitulina) numbers in Glacier Bay National Park, Alaska, 1992-2002. Marine Mammal Science, 22: 167-189.

McCarthy MA, Burgman MA, Ferson S, 1995. Sensitivity analysis for models of population viability. Biological Conservation, 73 (2): 93-100.

Milsom TP, Langton SD, Parkin WK, Peel S, Bishop JD, Hart JD, Moore NP, 2000. Habitat Models of Bird Species' Distribution: an Aid to The Management of Coastal Grazing Marshes. Journal of Applied Ecology, 37: 706-727.

Muthén LK, Muthén B, 2006. Mplus: User's guide. Los Angeles, CA: Muthén \& Muthén

O'Hara RB, 2005. Species richness estimators: How many species can dance on the head of a pin? Journal of Animal Ecology, 74: 375-386.

O'Hara RB, Kotze DJ, 2010. Do not log-transform count data. Methods in Ecology and Evolution. 1: 118-122.

Onmuş O, 2008. Gediz Deltası'nda üreyen su kuşu türlerinin yuvalama alanlarının izlenmesi ve bu kolonilerin yönetilmesi Ege Üniversitesi Fen Bilimleri Enstitüsü, Doktora Tezi (Basılmamış), İzmir.

Rékási J, Rozsa L, Kiss BJ, 1997. Patterns in the distribution of avian lice (Phthiraptera: Amblycera, Ischnocera). Journal of Avian Biology, 150-156.

Ridout M, Clarice GBD, John H, 1998. Models for count data with many zeros. International Biometric Conference. Cape Town.

Small RJ, Pendleton GW, Pitcher KW, 2003. Trends in abundance of Alaska harbor seals, 1983-2002. Marine Mammal Science, 19: 344-362.

Ver Hoef JM, Boveng PL, 2007. Quasi Poisson vs. negative binomial regression: how should we model overdispersed count data?. Ecology, 88 (11): 2766-2772.

Wang P, Putterman ML, 1998. Mixed logistic regression models. Journal of Agriculture Biological and Environmental Statistics, 3 (2): 175-200.

Wedderburn RWM, 1974. Quasi-likelihood functions,generalized linear models, and the Gauss-Newton method. Biometrika, 61: 439-447.

Yesilova A, Denizhan E, 2016. Modeling mite counts using poisson and negative binomial regressions. Fresenius Environmental Bulletın, 25 (11): 5062-5066

Yeşilova A, Özgökçe MS, Atlıhan R, Polat Yıldız Ş, Karaca İ, Ser G, 2016. Modeling of the arthropod population densities in the coastal band of Lake Van using mixture poison regression. Fresenius Environmental Bulletin, 25: 1768-1778.

Yuan Y, Zeng G, Liang J, Li X, Li Z, Zhang C, Yu X, 2014. Effects of landscape structure, habitat and human disturbance on birds: a case study in East Dongting Lake wetland. Ecological Engineering, 67: 67-75. 